\title{
Trace element analysis of whole-rock glass beads of geological reference materials by Nd:YAG UV 213 nm LA-ICP-MS
}

\author{
Chan-Soo Park, Hyung Seon Shin, Haeyoung Oh, Hana Cho and Albert Chang-sik Cheong*
}

\begin{abstract}
Background: A trace element composition of rock samples is difficult to determine when they contain refractory minerals that are hardly dissolved with conventional acid digestion techniques. Fused glass beads of rock samples could be an adequate target to circumvent this problem. We here report inductively coupled plasma-mass spectrometry (ICP-MS) results for geological reference materials (GRMs) prepared to normal- (sample/flux $=1: 5$ ) and low-dilution (sample/flux = 1:2) glass beads by using Nd:YAG UV 213-nm laser ablation system.

Findings: Concentrations of 24 trace elements ( $\mathrm{Ba}, \mathrm{Hf}, \mathrm{Nb}, \mathrm{Rb}, \mathrm{Sr}$, Ta, Th, $\mathrm{U}, \mathrm{Y}, \mathrm{Zr}$, and 14 rare earth elements (REEs)) were analyzed for three USGS GRMs (G-3 granite, AGV-2 andesite, and BHVO-2 basalt). Each analysis for the GRM beads was performed as spot (ca. $55 \mu \mathrm{m}$ diameter) analysis with 120-s ablation time. The depth-to-diameter ratio of the laser spot was low $(<4)$ enough to prevent significant elemental fractionation. The NIST612 glass and ${ }^{29}$ Si were employed as the external standard and the internal standard element, respectively. When the middle half of time-integrated data was taken to minimize the fractionation effect, the low-dilution fused glasses yielded reproducible and accurate results for all analyzed elements. In the case of normal-dilution fused glasses, comparable precision and accuracy were obtained only for elements with concentrations higher than $1 \mathrm{\mu g} \mathrm{g}^{-1}$, likely resulting from higher dilution ratios.
\end{abstract}

Conclusions: Low-dilution glass beads can be an adequate target to analyze trace element composition of rock samples by using the laser ablation ICP-MS. This simple and rapid technique can be applied directly to the same glass beads prepared for major elemental analysis using the XRF.

Keywords: Laser ablation-ICP-MS, Trace element analysis, Low-dilution glass bead, Geological reference material

\section{Introduction}

Trace element data provide an efficient tool to investigate various geologic issues such as the petrogenesis and geotectonic discrimination of igneous rocks (e.g., Rollinson 1993). Inductively coupled plasma-mass spectrometry (ICP-MS) is the most widely accepted analytical technique for rock samples due to its low detection limit and high sample throughput. However, the application of this method requires complete dissolution of rock samples, which is difficult for samples containing refractory minerals that are commonly enriched in $\mathrm{Zr}$, Hf, and rare earth elements (REEs). It is well known that open acid and

\footnotetext{
* Correspondence: ccs@kbsi.re.kr

Korea Basic Science Institute, 162 Yeongudanji-ro, Cheongwon-gu, Cheongju Chungbuk 28119, Republic of Korea
}

microwave-assisted digestion methods can not completely dissolve the refractory minerals (Hall and Plant 1992, Totland et al. 1992, 1995, Wu et al. 1996, Fan and Kerrich 1997, Yu et al. 2001, Navarro et al. 2008). Fused glass beads can be an adequate target to overcome this problem (Park et al. 2013 and references therein).

Laser ablation ICP-MS (LA-ICP-MS) has been adopted as a rapid and simple technique for the microanalysis of trace elements (Jackson et al. 1992, Norman et al. 1996, 1998, Horn et al. 1997). The first generation of a widely used laser ablation (i.e., Nd:YAG $266 \mathrm{~nm}$ ), however, yielded relatively low precision and accuracy ( \pm 20 to $30 \%$ errors) on geological samples for both normal- (sample/flux =ca. 1:5) and lower dilution glass beads (Lahaye et al. 1997, Taylor et al. 1997, Norman et al. 1998, Chen et al. 2000, Orihashi and Hirata 2003, 
Kurosawa et al. 2006). In this note, we adopted Nd:YAG UV $213 \mathrm{~nm}$ LA-ICP-MS to determine trace element concentrations of glass beads prepared from a series of geological reference materials (GRMs).

\section{Experimental procedures}

All experimental works, including sample preparation and instrumental analysis, were performed at the Korea Basic Science Institute in Ochang.

\section{Samples and sample preparation}

The samples analyzed in this study were fused glass beads prepared from igneous silicate rock reference powders provided by the USGS; AGV-2 (andesite), BHVO-2 (basalt), and G-3 (granite). The rock powders were dried overnight at $105{ }^{\circ} \mathrm{C}$ and oxidized in an electric muffle furnace at $950{ }^{\circ} \mathrm{C}$ for 30 min with a mixed fusion flux consisting of pure-grade $(>99.98 \%)$ lithium metaborate $\left(\mathrm{LiBO}_{2}\right)$ and lithium tetraborate $\left(\mathrm{Li}_{2} \mathrm{~B}_{4} \mathrm{O}_{7}\right)$ (Claisse, mixing proportion $=65: 35 \%$, melting point $=$ $\left.825{ }^{\circ} \mathrm{C}\right)$. The normal-dilution glass beads were prepared by mixing $1.2 \mathrm{~g}$ of sample powder with $6.0 \mathrm{~g}$ of fusion flux. To prepare the low-dilution glass beads, $2.5 \mathrm{~g}$ of sample were mixed with $5.0 \mathrm{~g}$ of flux. The sample and flux mixtures were made into glass beads using a furnace-type automatic fusion machine (Katanax K2) at $1020{ }^{\circ} \mathrm{C}$ for $10 \mathrm{~min}$. The cooled low-dilution beads were ground in an alumina ball mill and fused again for 10 min to secure the homogeneity of the sample matrices.

\section{Instrumental analysis}

The ICP-MS instrument used in this study was an $\mathrm{X}$ series 2 quadrupole ICP-MS from Thermo Elemental. The ICP-MS instrument was coupled to a frequency quintuple Nd:YAG UV $213 \mathrm{~nm}$ laser. A total of 24 trace elements $(\mathrm{Ba}, \mathrm{Hf}, \mathrm{Nb}, \mathrm{Rb}, \mathrm{Sr}, \mathrm{Ta}, \mathrm{Th}, \mathrm{U}, \mathrm{Y}, \mathrm{Zr}$, and 14 REEs) were analyzed for this study. Laser ablation parameters were as follows: spot diameter, $55 \mu \mathrm{m}$; dwell time, $30 \mathrm{~ms}$; pulse energy, $0.54 \mathrm{~mJ}$; and pulse repetition, $10 \mathrm{~Hz}$. One analysis consists of pre-ablation (30 s) for instrumental background, ablation and data reduction (120 s), and wash out (30 s), leading to complete analysis within approximately $3 \mathrm{~min}$. Data reduction was performed using the Glitter software. The NIST612 glass reference material was also analyzed as an external standard.

Table 1 presents trace element composition of the flux by using solution-ICP-MS. Measurable values $\left(>0.1 \mu \mathrm{g} \mathrm{g}^{-1}\right)$ were detected for six elements. Final concentrations were acquired by subtracting the background values of the flux from the calculated values by the Glitter software.

LA-ICP-MS analysis with an area of a micrometer scale may cause a problem with the homogeneity of the
Table 1 Trace element composition of the flux $\left(\mu \mathrm{g} \mathrm{g}^{-1}\right)$

\begin{tabular}{|c|c|c|}
\hline Element & Measured value & SD \\
\hline$\overline{\text { As }}$ & 0.3 & 0.16 \\
\hline $\mathrm{Ba}$ & 0.22 & 0.04 \\
\hline $\mathrm{Be}$ & 0.78 & 0.01 \\
\hline $\mathrm{Cd}$ & 1.01 & 0.02 \\
\hline $\mathrm{Ce}$ & 0.23 & 0.02 \\
\hline Co & 0.04 & 0.01 \\
\hline $\mathrm{Cr}$ & 1.76 & 0.07 \\
\hline Cs & 0.22 & 0.01 \\
\hline $\mathrm{Cu}$ & 0.35 & 0.03 \\
\hline Dy & 0.002 & 0.001 \\
\hline $\mathrm{Er}$ & 0.001 & 0.001 \\
\hline $\mathrm{Ga}$ & 0.16 & 0.05 \\
\hline La & 0.27 & 0.01 \\
\hline $\mathrm{Nd}$ & 0.31 & 0.01 \\
\hline $\mathrm{Ni}$ & 0.68 & 0.02 \\
\hline $\mathrm{Pb}$ & 0.92 & 0.06 \\
\hline $\operatorname{Pr}$ & 0.02 & 0.002 \\
\hline Sm & 0.01 & 0.001 \\
\hline $\mathrm{Sr}$ & 0.28 & 0.01 \\
\hline Th & 0.02 & 0.003 \\
\hline U & 0.02 & 0.002 \\
\hline V & 6.11 & 0.27 \\
\hline Y & 0.02 & 0.002 \\
\hline $\mathrm{Zn}$ & 0.22 & 0.27 \\
\hline
\end{tabular}

glass beads. To check this problem, a total of 10 spot analyses were performed with $500-\mu \mathrm{m}$ intervals. Operating conditions and instrumental parameters are summarized in Table 2.

\section{Results and discussion Oxide interference}

It is well known that oxide interference (e.g., $\mathrm{BaO}^{+}, \mathrm{LaO}^{+}$, $\mathrm{CeO}^{+}$, etc.) can cause large analytical errors on middle to heavy REEs in the solution-ICP-MS technique. However, in the case of laser ablation mode, the efficiency of oxide formation is generally one tenth that of conventional solution nebulization. Monitoring the $\mathrm{ThO}^{+} / \mathrm{Th}^{+}$ratio is useful for checking the oxide interference because there is no naturally occurring isotope at the $\mathrm{ThO}^{+}$mass (248), and the $\mathrm{Th}-$ $\mathrm{O}$ bond is among the strongest known for oxides (Hu et al. 2008). In this study, the $\mathrm{ThO}^{+} / \mathrm{Th}^{+}$ratio on the NIST612 standard could be controlled below $1 \%$ during the analyses, and thus, the oxide interference was negligible.

\section{Elemental fractionation}

For LA-ICP-MS, constant and homogeneous ablation and aerosol transport is essentially required to obtain 
Table 2 LA-ICP-MS operating conditions

\begin{tabular}{ll}
\hline ICP-MS & \\
Model & Thermo Elemental X series 2 \\
Incident power & $1200 \mathrm{~W}$ \\
Gas flows & $13 \mathrm{~L} \mathrm{~min}^{-1}$ \\
Plasma & $0.80 \mathrm{~L} \mathrm{~min}^{-1}$ \\
Auxiliary & $0.70 \mathrm{~L} \mathrm{~min}^{-1}$ \\
Carrier & Platinum \\
Cones & $30 \mathrm{~ms}$ \\
Dwell time & $<1 \%$ \\
ThO & /Th \\
Laser ablation & \\
Model & $\mathrm{New} \mathrm{wave} \mathrm{UP-213}$ \\
Laser & $\mathrm{UV} \mathrm{Nd:YAG} \mathrm{213} \mathrm{nm}$ \\
Pulse energy & $0.54 \mathrm{~mJ}$ \\
Repetition rate & $10 \mathrm{~Hz}$ \\
\hline
\end{tabular}

high precision on elemental concentrations. Although the $266 \mathrm{~nm}$ laser is known to reduce fractionation compared with an infrared laser (1064 $\mathrm{nm}$ wavelength), the fractionation still remained considerable compared with shorter-wavelength laser systems (Gonzalez et al. 2002, Jochum et al. 2007). Relatively large analytical errors (more than $20 \%$ ) reported from a UV $266 \mathrm{~nm}$ laser could be attributed mainly to elemental fractionation during laser ablation and to contamination or loss of elements during glass preparation (Norman et al. 1998).

We examined the capability of Nd:YAG UV $213 \mathrm{~nm}$ laser to overcome the elemental fractionation. For accurate quantitative analysis, the elemental ratios should be stable over the entire reduction period. This stability was checked using the ${ }^{238} \mathrm{U} /{ }^{232}$ Th ratio in the NIST612 glass. Because the first ionization potentials of $U$ and Th are similar to each other, this isotope ratio should approach to the U/Th ratio of NIST612 (=ca. 1; Guillong et al. 2003). The ${ }^{238} \mathrm{U} /{ }^{232} \mathrm{Th}$, and some other geochemically important elemental ratios such as ${ }^{139} \mathrm{La} /{ }^{172} \mathrm{Yb},{ }^{93} \mathrm{Nb} /$ ${ }^{89} \mathrm{Y},{ }^{85} \mathrm{Rb} /{ }^{89} \mathrm{Y},{ }^{90} \mathrm{Zr} /{ }^{178} \mathrm{Hf}$, and ${ }^{90} \mathrm{Zr} /{ }^{89} \mathrm{Y}$ of NIST612 are listed in Table 3. As shown in Fig. 1, relative standard deviations (RSDs) of these ratios were comparatively high during the transient signal interval (the first $30 \mathrm{~s}$ ), and then the signals became stable. We therefore set the reduction interval for a total of $60 \mathrm{~s}$ from 30 to $90 \mathrm{~s}$ after ablation to minimize the fractionation effect.

The depth-to-diameter ratio of the laser spot is also an important parameter governing elemental fractionation (Eggins et al. 1998; Mank and Mason, 1999; Borisov et al. 2000; Horn et al. 2000). Mank and Mason (1999) showed that elemental fractionation becomes significant for some elements when the depth/diameter ratio of the
Table 3 Some elemental ratios for NIST 612 glass

\begin{tabular}{lllll}
\hline Elemental ratio & Initial $30 \mathrm{~s}$ & Reduction interval $(60 \mathrm{~s})$ & Final $30 \mathrm{~s}$ \\
\hline${ }^{238} \mathrm{U} /{ }^{232} \mathrm{Th}$ & Avg & 1.05 & 1.02 & 1.02 \\
& SD & 0.08 & 0.02 & 0.04 \\
& RSD (\%) & 7.62 & 2.09 & 3.60 \\
${ }^{139} \mathrm{La} /{ }^{172} \mathrm{Yb}$ & Avg & 1.31 & 1.25 & 1.26 \\
& SD & 0.25 & 0.04 & 0.05 \\
& RSD (\%) & 19.13 & 3.26 & 3.77 \\
${ }^{93} \mathrm{Nb} /{ }^{89} \mathrm{Y}$ & Avg & 0.82 & 0.82 & 0.82 \\
& SD & 0.08 & 0.03 & 0.03 \\
& RSD (\%) & 9.84 & 3.18 & 3.43 \\
${ }^{85} \mathrm{Rb} /{ }^{89} \mathrm{Y}$ & Avg & 0.52 & 0.53 & 0.52 \\
& SD & 0.03 & 0.01 & 0.02 \\
& RSD (\%) & 5.79 & 2.83 & 3.75 \\
${ }^{90} \mathrm{Zr} /{ }^{178} \mathrm{Hf}$ & Avg & 0.85 & 0.86 & 0.87 \\
& SD & 0.07 & 0.04 & 0.04 \\
& RSD (\%) & 8.33 & 4.18 & 4.34 \\
${ }^{90} \mathrm{Zr} /{ }^{89} \mathrm{Y}$ & Avg & 0.52 & 0.50 & 0.50 \\
& SD & 0.09 & 0.02 & 0.02 \\
& RSD (\%) & 18.19 & 3.12 & 3.39 \\
\hline Avg averge & SD stand &
\end{tabular}

Avg average; $S D$ standard deviation; $R S D$ relative standard deviation

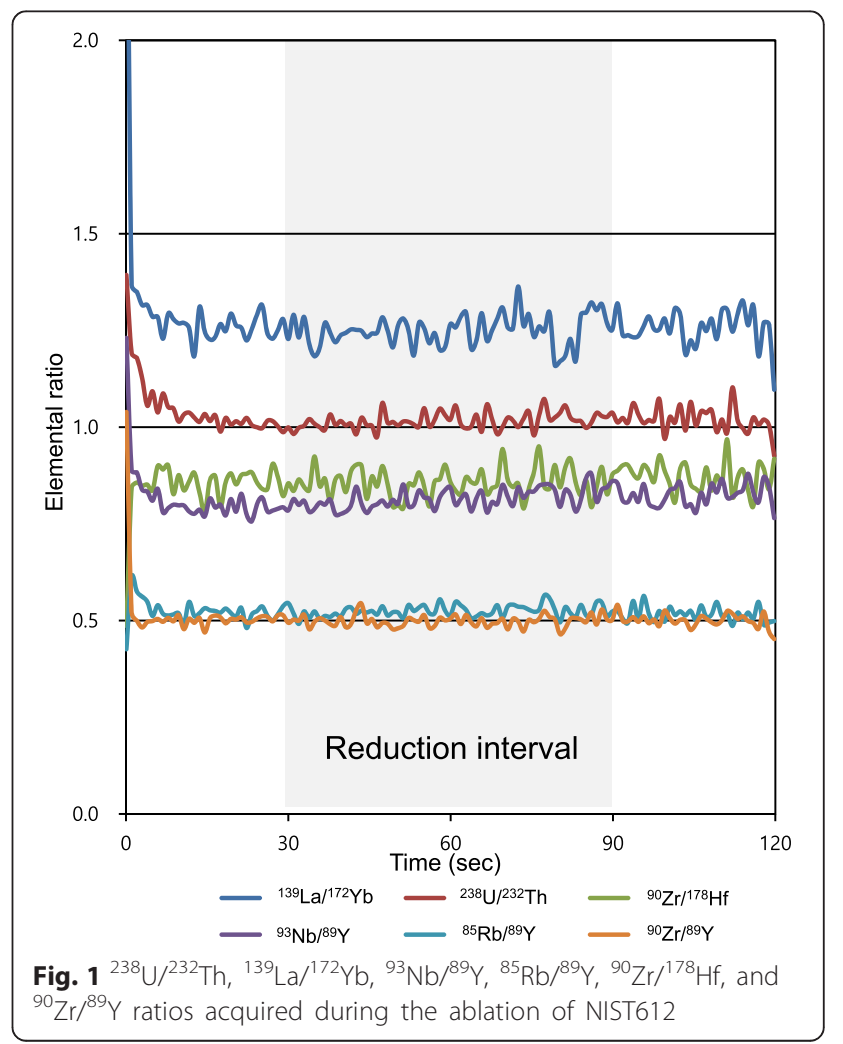




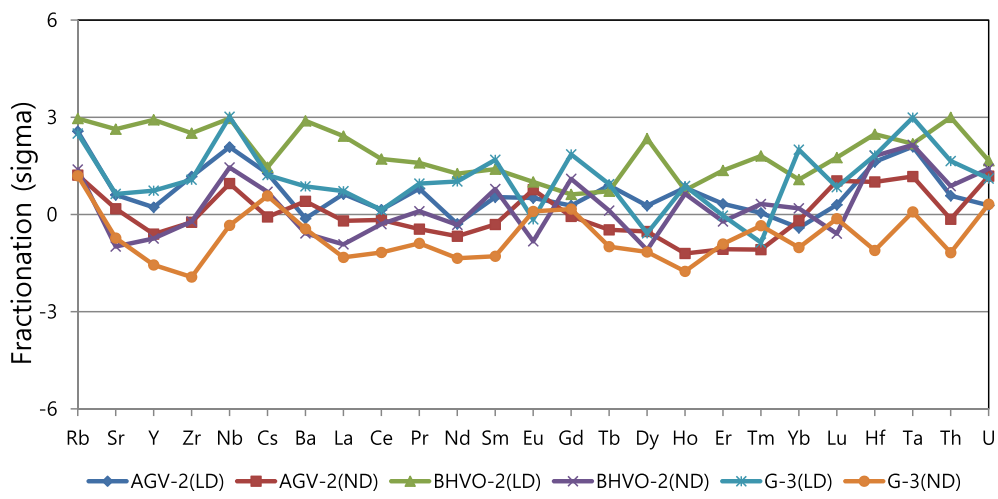

Fig. 2 Calculated fractionation of elements from the GRM beads. LD low-dilution glass bead; ND normal-dilution glass bead

Table 4 Mean results \pm standard deviation and reference values $\left(\mu \mathrm{g} \mathrm{g}^{-1}\right)$

\begin{tabular}{|c|c|c|c|c|c|c|c|c|c|}
\hline \multirow[t]{3}{*}{ Element } & \multicolumn{3}{|l|}{ AGV-2 } & \multicolumn{3}{|l|}{ BHVO-2 } & \multicolumn{3}{|l|}{$G-3$} \\
\hline & \multirow{2}{*}{$\begin{array}{l}\mathrm{A}] \\
\text { Mean } \pm \mathrm{SD}\end{array}$} & \multirow{2}{*}{$\begin{array}{l}{[\mathrm{B}]} \\
\text { Mean } \pm \text { SD }\end{array}$} & \multirow[t]{2}{*}{ [1] } & \multirow{2}{*}{$\begin{array}{l}\mathrm{A}] \\
\text { Mean } \pm \text { SD }\end{array}$} & \multirow{2}{*}{$\begin{array}{l}{[\mathrm{B}]} \\
\text { Mean } \pm \text { SD }\end{array}$} & \multirow[t]{2}{*}{ [2] } & \multirow{2}{*}{$\begin{array}{l}\text { A] } \\
\text { Mean } \pm \text { SD }\end{array}$} & \multirow{2}{*}{$\begin{array}{l}{[\mathrm{B}]} \\
\text { Mean } \pm \text { SD }\end{array}$} & \multirow[t]{2}{*}{ [3] } \\
\hline & & & & & & & & & \\
\hline $\mathrm{Rb}$ & $71.6 \pm 2.9$ & $71.6 \pm 2.6$ & $68.6 \pm 2.3$ & $10.0 \pm 0.4$ & $9.6 \pm 0.6$ & $9.2 \pm 0.4$ & $178.6 \pm 6.9$ & $174.3 \pm 11.3$ & $171 \pm 6$ \\
\hline $\mathrm{Sr}$ & $682 \pm 25$ & $679 \pm 28$ & $658 \pm 17$ & $406 \pm 12$ & $406 \pm 16$ & $402 \pm 18$ & $469 \pm 19$ & $463 \pm 19$ & $463 \pm 4$ \\
\hline Y & $19.9 \pm 0.8$ & $20.2 \pm 0.9$ & $20 \pm 1$ & $26.3 \pm 0.9$ & $25.8 \pm 1.1$ & $25.8 \pm 1.2$ & $10.4 \pm 0.5$ & $10.8 \pm 0.5$ & $9.9 \pm 0.2$ \\
\hline $\mathrm{Zr}$ & $240 \pm 10$ & $238 \pm 10$ & $230 \pm 4$ & $176 \pm 6$ & $167 \pm 5$ & $166 \pm 7$ & $370 \pm 15$ & $369 \pm 15$ & $364 \pm 8$ \\
\hline $\mathrm{Nb}$ & $14.1 \pm 0.6$ & $13.7 \pm 0.7$ & $15 \pm 1$ & $17.7 \pm 0.6$ & $18.4 \pm 0.7$ & $17.5 \pm 0.3$ & $13.4 \pm 0.7$ & $12.4 \pm 0.7$ & $13.9 \pm 1.0$ \\
\hline $\mathrm{Ba}$ & $1139 \pm 55$ & $1151 \pm 77$ & $1140 \pm 32$ & $131 \pm 5$ & $131 \pm 5$ & $129 \pm 4$ & $1941 \pm 76$ & $1882 \pm 80$ & $1914 \pm 58$ \\
\hline La & $39.7 \pm 1.6$ & $39.7 \pm 1.8$ & $38 \pm 1$ & $15.5 \pm 0.5$ & $15.2 \pm 0.6$ & $15.1 \pm 0.5$ & $93.4 \pm 3.5$ & $91.6 \pm 3.2$ & $91.0 \pm 0.3$ \\
\hline $\mathrm{Ce}$ & $71 \pm 3$ & $71 \pm 3$ & $68 \pm 3$ & $38 \pm 1$ & $38 \pm 2$ & $37 \pm 1$ & $168 \pm 6$ & $163 \pm 6$ & $167 \pm 2$ \\
\hline $\operatorname{Pr}$ & $8.1 \pm 0.3$ & $8.2 \pm 0.4$ & $8.3 \pm 0.6$ & $5.2 \pm 0.2$ & $5.3 \pm 0.2$ & $5.3 \pm 0.1$ & $16.6 \pm 0.7$ & $16.3 \pm 0.7$ & $16.9 \pm 0.2$ \\
\hline $\mathrm{Nd}$ & $30.9 \pm 1.3$ & $31.1 \pm 1.7$ & $30 \pm 2$ & $25.0 \pm 1.0$ & $25.2 \pm 1.5$ & $24.2 \pm 0.5$ & $55.2 \pm 2.7$ & $54.7 \pm 2.0$ & $55.0 \pm 0.7$ \\
\hline $\mathrm{Sm}$ & $5.7 \pm 0.4$ & $5.7 \pm 0.4$ & $5.7 \pm 0.3$ & $6.0 \pm 0.3$ & $6.3 \pm 0.4$ & $6.1 \pm 0.2$ & $7.4 \pm 0.5$ & $7.5 \pm 0.5$ & $7.4 \pm 0.2$ \\
\hline $\mathrm{Eu}$ & $1.51 \pm 0.09$ & $1.49 \pm 0.13$ & $1.54 \pm 0.10$ & $2.00 \pm 0.10$ & $2.07 \pm 0.13$ & $2.07 \pm 0.05$ & $1.42 \pm 0.09$ & $1.35 \pm 0.11$ & $1.5 \pm 0.1$ \\
\hline $\mathrm{Gd}$ & $4.65 \pm 0.29$ & $4.79 \pm 0.39$ & $4.69 \pm 0.26$ & $6.42 \pm 0.34$ & $6.41 \pm 0.43$ & $6.2 \pm 0.2$ & $4.42 \pm 0.28$ & $4.44 \pm 0.36$ & $4.0 \pm 0.5$ \\
\hline $\mathrm{Tb}$ & $0.62 \pm 0.04$ & $0.66 \pm 0.06$ & $0.64 \pm 0.04$ & $0.91 \pm 0.05$ & $0.93 \pm 0.07$ & $0.93 \pm 0.02$ & $0.45 \pm 0.03$ & $0.47 \pm 0.04$ & $0.46 \pm 0.04$ \\
\hline Dy & $3.69 \pm 0.21$ & $3.86 \pm 0.31$ & $3.6 \pm 0.2$ & $5.57 \pm 0.26$ & $5.71 \pm 0.35$ & $5.3 \pm 0.1$ & $2.17 \pm 0.17$ & $2.23 \pm 0.19$ & $2.17 \pm 0.08$ \\
\hline Ho & $0.69 \pm 0.04$ & $0.71 \pm 0.06$ & $0.71 \pm 0.08$ & $1.02 \pm 0.05$ & $1.02 \pm 0.07$ & $0.99 \pm 0.02$ & $0.36 \pm 0.03$ & $0.37 \pm 0.04$ & $0.36 \pm 0.07$ \\
\hline $\mathrm{Er}$ & $1.86 \pm 0.13$ & $1.92 \pm 0.17$ & $1.79 \pm 0.11$ & $2.52 \pm 0.13$ & $2.65 \pm 0.18$ & $2.53 \pm 0.05$ & $0.89 \pm 0.08$ & $0.97 \pm 0.11$ & $0.92 \pm 0.06$ \\
\hline $\mathrm{Tm}$ & $0.26 \pm 0.02$ & $0.29 \pm 0.04$ & $0.26 \pm 0.02$ & $0.33 \pm 0.02$ & $0.34 \pm 0.04$ & $0.33 \pm 0.01$ & $0.12 \pm 0.02$ & $0.13 \pm 0.02$ & $0.12 \pm 0.01$ \\
\hline $\mathrm{Yb}$ & $1.76 \pm 0.15$ & $1.88 \pm 0.20$ & $1.6 \pm 0.2$ & $2.12 \pm 0.14$ & $2.16 \pm 0.18$ & $1.96 \pm 0.04$ & $0.81 \pm 0.09$ & $0.87 \pm 0.12$ & $0.72 \pm 0.10$ \\
\hline Lu & $0.27 \pm 0.02$ & $0.29 \pm 0.03$ & $0.25 \pm 0.01$ & $0.29 \pm 0.02$ & $0.32 \pm 0.03$ & $0.27 \pm 0.01$ & $0.10 \pm 0.02$ & $0.11 \pm 0.02$ & $0.12 \pm 0.02$ \\
\hline $\mathrm{Hf}$ & $5.41 \pm 0.27$ & $5.42 \pm 0.31$ & $5.08 \pm 0.20$ & $4.60 \pm 0.21$ & $4.57 \pm 0.28$ & $4.4 \pm 0.2$ & $9.11 \pm 0.42$ & $9.37 \pm 0.47$ & $8.8 \pm 0.5$ \\
\hline $\mathrm{Ta}$ & $0.92 \pm 0.05$ & $0.92 \pm 0.07$ & $0.89 \pm 0.08$ & $1.22 \pm 0.06$ & $1.26 \pm 0.08$ & $1.16 \pm 0.05$ & $0.95 \pm 0.06$ & $0.96 \pm 0.06$ & \\
\hline Th & $6.34 \pm 0.25$ & $6.47 \pm 0.37$ & $6.1 \pm 0.6$ & $1.28 \pm 0.07$ & $1.19 \pm 0.08$ & $1.22 \pm 0.08$ & $24.70 \pm 0.89$ & $25.34 \pm 0.96$ & $24.9 \pm 0.5$ \\
\hline U & $1.97 \pm 0.09$ & $1.94 \pm 0.15$ & $1.88 \pm 0.16$ & $0.40 \pm 0.03$ & $0.37 \pm 0.04$ & $0.42 \pm 0.01$ & $2.21 \pm 0.10$ & $2.06 \pm 0.12$ & $2.14 \pm 0.09$ \\
\hline
\end{tabular}

[A] Low-dilution glass bead (this study), [B] normal-dilution glass bead (this study), [1] recommended value (USGS), [2] Cotta and Enzweiler (2012), [3] Park et al. (2013) 
ablation pit is higher than six, which corresponds to a $50 \%$ reduction in analyte response. For the BHVO-2 bead, we confirmed that the depth of laser pit was ca. $220 \mu \mathrm{m}$ after the total ablation time (120 s). The spot depth to the end of data reduction (90 s) was ca. $165 \mu \mathrm{m}$, corresponding to a depth/diameter ratio of ca. 3. Such a low depth/diameter ratio suggests that significant elemental fractionation may not occur during the laser ablation.

Elemental fractionation was calculated by dividing the reduction interval across the time-resolved signal into two equal parts. The difference between independently calculated concentrations for each part ( conc $_{1}$ and conc $_{2}$ ) was compared with the results obtained using the entire signal ( conc $\left._{\text {total }}\right)$ :

$$
\begin{aligned}
& \text { Fractionation }(\%)=\left(\left(\text { conc }_{1}-\text { conc }_{2}\right) / \text { conc }_{\text {total }}\right) \\
& \times 100
\end{aligned}
$$

Assuming that no significant fractionation occurred for a sample run, $99 \%$ of data will plot below three (3 sigma).

Table 5 Selected mass number and minimum detection limits (MDL, $99 \%$ confidence)

\begin{tabular}{|c|c|c|}
\hline Element & Mass & $\operatorname{MDL}\left(\mu g g^{-1}\right)$ \\
\hline $\mathrm{Rb}$ & 85 & 0.15 \\
\hline $\mathrm{Sr}$ & 88 & 0.07 \\
\hline Y & 89 & 0.06 \\
\hline $\mathrm{Zr}$ & 90 & 0.11 \\
\hline $\mathrm{Nb}$ & 93 & 0.08 \\
\hline $\mathrm{Ba}$ & 137 & 0.28 \\
\hline La & 139 & 0.07 \\
\hline $\mathrm{Ce}$ & 140 & 0.04 \\
\hline $\operatorname{Pr}$ & 141 & 0.22 \\
\hline $\mathrm{Nd}$ & 146 & 0.22 \\
\hline $\mathrm{Sm}$ & 147 & 0.20 \\
\hline $\mathrm{Eu}$ & 153 & 0.04 \\
\hline $\mathrm{Gd}$ & 157 & 0.23 \\
\hline $\mathrm{Tb}$ & 159 & 0.10 \\
\hline Dy & 163 & 0.10 \\
\hline Ho & 165 & $<0.001$ \\
\hline $\mathrm{Er}$ & 166 & $<0.001$ \\
\hline $\mathrm{Tm}$ & 169 & 0.04 \\
\hline $\mathrm{Yb}$ & 172 & $<0.001$ \\
\hline Lu & 175 & $<0.001$ \\
\hline $\mathrm{Hf}$ & 178 & 0.02 \\
\hline $\mathrm{Ta}$ & 181 & 0.04 \\
\hline Th & 232 & $<0.001$ \\
\hline$U$ & 238 & 0.03 \\
\hline
\end{tabular}

Figure 2 shows that our results meet this criteria for all analytes in the GRM beads.

\section{Precision and accuracy}

When the reduction interval is set for the middle half (60 s) of the total integration and the NIST612 glass and ${ }^{29} \mathrm{Si}$ are respectively used as the external standard and the internal standard element, the GRM beads yield trace element compositions listed in Table 4. The NIST612 glass was analyzed in triplicate for each sample analysis to calibrate the variation in signal intensity over time. We employed $\mathrm{Si}$ instead of $\mathrm{Ca}$, considering the relatively low concentrations of $\mathrm{Ca}(<10 \%)$ in the GRMs analyzed here. Table 4 also presents recommended trace element compositions of the GRMs. The minimum detection limits (MDL) at the $99 \%$ confidence level were calculated based on Poisson counting statistics.

$$
\mathrm{MDL}=2.3 *(2 B)^{0.5}
$$

Table 6 Relative standard deviation (RSD) of Si normalized

\begin{tabular}{|c|c|c|c|c|c|c|}
\hline \multirow[t]{2}{*}{ Element } & \multicolumn{2}{|c|}{ AGV-2 } & \multicolumn{2}{|c|}{ BHVO-2 } & \multicolumn{2}{|l|}{ G-3 } \\
\hline & {$[\mathrm{A}]$} & {$[B]$} & {$[\mathrm{A}]$} & {$[\mathrm{B}]$} & {$[\mathrm{A}]$} & {$[B]$} \\
\hline $\mathrm{Rb}$ & 2.4 & 2.3 & 3.5 & 4.2 & 1.5 & 2.0 \\
\hline $\mathrm{Sr}$ & 2.5 & 1.2 & 2.3 & 1.8 & 1.3 & 1.6 \\
\hline Y & 2.5 & 1.7 & 2.3 & 4.8 & 1.9 & 4.6 \\
\hline $\mathrm{Zr}$ & 2.8 & 1.9 & 2.5 & 2.1 & 1.3 & 1.7 \\
\hline $\mathrm{Nb}$ & 3.9 & 3.0 & 2.3 & 2.5 & 2.9 & 3.2 \\
\hline $\mathrm{Ba}$ & 3.2 & 1.7 & 2.8 & 2.9 & 1.4 & 1.7 \\
\hline La & 3.6 & 2.5 & 2.1 & 3.1 & 1.4 & 1.6 \\
\hline $\mathrm{Ce}$ & 3.0 & 2.4 & 2.5 & 1.5 & 1.2 & 1.8 \\
\hline $\operatorname{Pr}$ & 2.9 & 3.3 & 2.6 & 3.5 & 1.5 & 1.8 \\
\hline $\mathrm{Nd}$ & 2.5 & 1.4 & 2.5 & 4.7 & 1.8 & 2.3 \\
\hline $\mathrm{Sm}$ & 4.0 & 7.4 & 5.5 & 6.5 & 6.2 & 7.9 \\
\hline $\mathrm{Eu}$ & 8.3 & 9.4 & 3.9 & 4.3 & 6.3 & 6.0 \\
\hline $\mathrm{Gd}$ & 5.5 & 7.8 & 3.7 & 9.0 & 5.3 & 6.6 \\
\hline $\mathrm{Tb}$ & 3.9 & 6.1 & 4.9 & 5.5 & 7.7 & 9.7 \\
\hline Dy & 5.8 & 8.1 & 4.8 & 3.6 & 5.3 & 7.4 \\
\hline $\mathrm{Ho}$ & 9.0 & 7.1 & 2.9 & 3.1 & 8.1 & 6.5 \\
\hline $\mathrm{Er}$ & 7.3 & 8.6 & 4.3 & 6.8 & 8.8 & 11.6 \\
\hline $\mathrm{Tm}$ & 9.5 & 17.3 & 5.2 & 9.0 & 7.1 & 27.4 \\
\hline $\mathrm{Yb}$ & 8.5 & 9.9 & 5.7 & 6.0 & 7.9 & 17.0 \\
\hline Lu & 8.6 & 7.0 & 6.7 & 9.7 & 9.1 & 20.8 \\
\hline $\mathrm{Hf}$ & 6.0 & 6.5 & 3.1 & 4.3 & 2.1 & 3.7 \\
\hline $\mathrm{Ta}$ & 8.2 & 6.0 & 3.2 & 4.2 & 4.3 & 6.0 \\
\hline Th & 4.3 & 4.6 & 5.1 & 7.9 & 1.1 & 2.2 \\
\hline$U$ & 7.0 & 4.9 & 9.2 & 7.9 & 3.0 & 5.8 \\
\hline
\end{tabular}
mean cps

[A] Low-dilution glass bead, [B] normal-dilution glass bead 
where $B$ is the total counts in the background interval. Table 5 shows MDL of our LA-ICP-MS analysis.

As listed in Table 6 and graphically displayed in Fig. 3, the RSDs (1 s) for counts per second (cps) normalized to $\mathrm{Si}$ were within $\pm 10 \%$ (mean), and no marked chemical heterogeneity of the matrix composition was observed in low-dilution glass beads. However, in the case of normal-dilution glass beads, a large scatter was shown for AGV-2 and G-3. Such a large scatter (11.6-27.4\% RSD) at less than 50 cps could be ascribed to low elemental concentrations, rather than to real inhomogeneity.

The precision of 10 replicate analyses for the lowdilution glass beads was acceptable, with the RSDs for most elements being $<10 \%$. The mean RSD values were $1.2-8.6 \%$ at concentrations above $1 \mu \mathrm{g} \mathrm{g}^{-1}$ and $4.4-9.6 \%$ at concentrations below $1 \mu \mathrm{g} \mathrm{g}^{-1}$. On the other hand, the mean RSD values for the normal-dilution glass beads were $1.0-13.5$ and $5.4-20.7 \%$ at concentrations above and below $1 \mu \mathrm{g} \mathrm{g}^{-1}$, respectively. The large deviations (10.020.7 \% RSD) observed for heavy REEs in a normal-dilution glass bead of G-3 might be due to their low concentrations resulting from high dilution ratio.

The recoveries and accuracy were assessed by comparing our results with recommended values provided by the supplier and/or literature data. Granite G-3 is the successor of G-2, one of the best analyzed reference materials, but they differ significantly in the content of most elements (Meisel et al. 2002). Our results for G-3 were compared with ICP-MS data reported using low-dilution glass bead digestion (Park et al. 2013). BHVO-2 data were compared with previous results by high-pressure bomb digestion (Cotta and Enzweiler 2012), and AGV-2 results were compared with the USGS recommended values. As shown in Fig. 4, our data for low-dilution glass beads were in good agreement with the recommended values for most elements but showed a slight deviation for $\mathrm{Rb}$ in

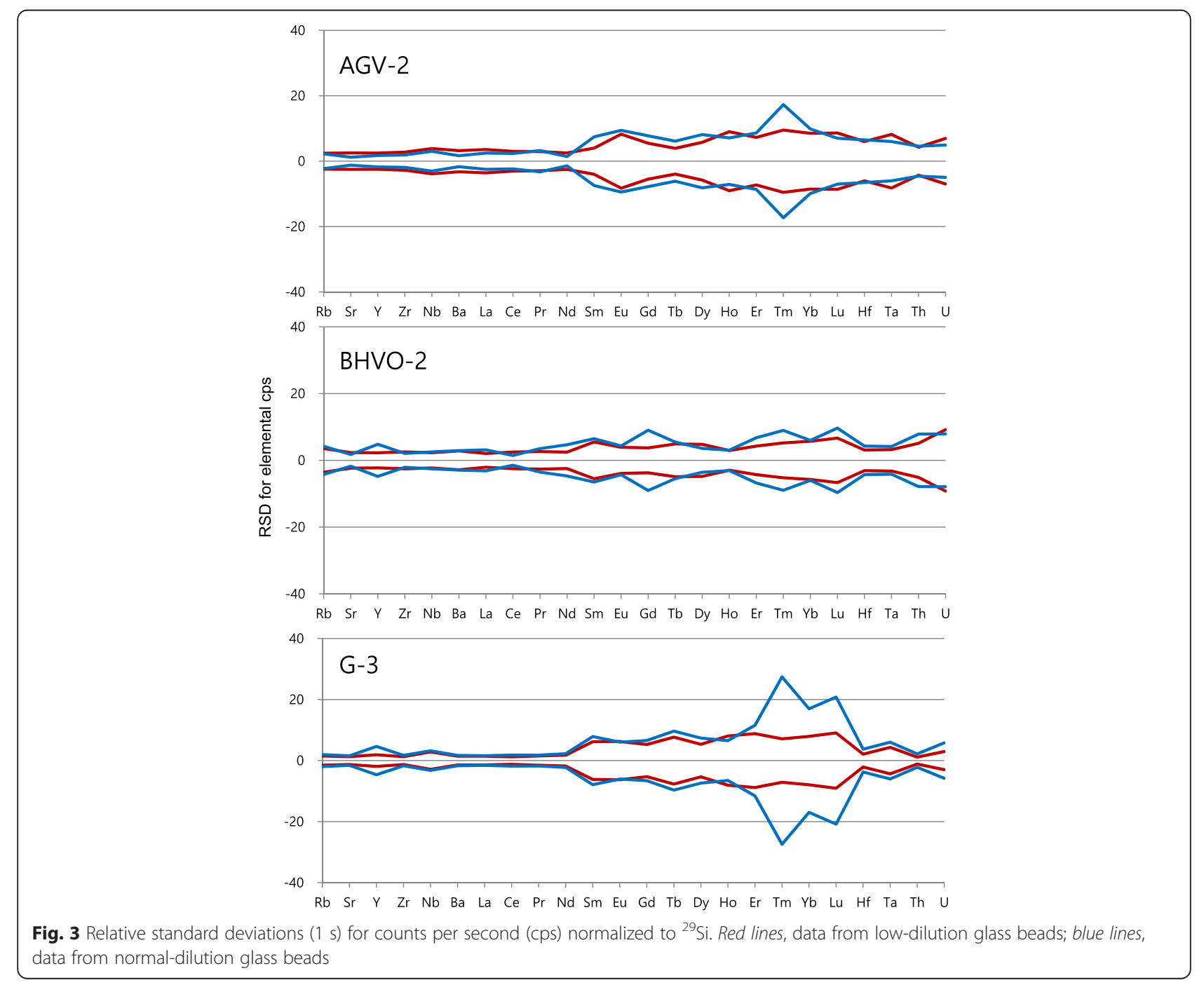



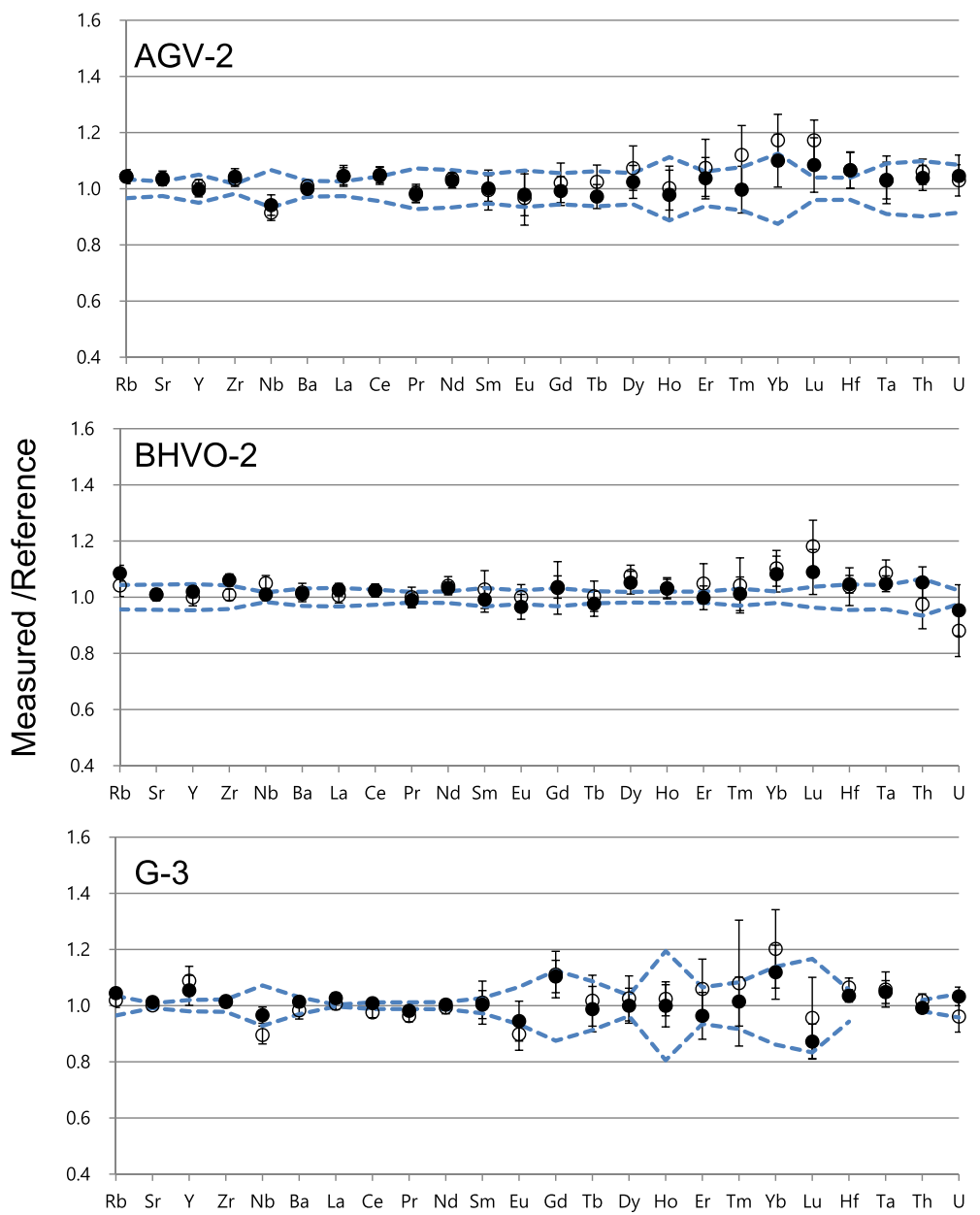

Fig. 4 Analytical results normalized to average recommended value. The error bar for each measured result represents one standard deviation. Dashed lines correspond to one standard deviation of reference values. Symbols: closed circles, data from low-dilution glass beads; open circles, data from normal-dilution glass beads

BHVO-2 and $\mathrm{Y}$ in G-3. In the case of normal-dilution glass beads, the results for $\mathrm{Lu}$ in BHVO-2 and $\mathrm{Y}$ and $\mathrm{Yb}$ in G-3 were not consistent with the reference values. Overall accuracy is clearly better in the lowdilution glass beads.

\section{Conclusion}

In this study, we optimized experimental conditions for minimizing elemental fractionation using a UV $213 \mathrm{~nm}$ LA-ICP-MS and obtained improved results compared to previous reports using the longer wavelength lasers. Our trace element data for a series of GRMs show good agreement with reference values, mostly within $10 \%$ relative uncertainty. We confirm that the lowdilution glass bead is a proper target material for trace element analysis of rock samples using the laser ablation technique. It is noted that this technique can be applied directly to the same glass beads prepared for the XRF analysis.

\section{Competing interests}

The authors declare that they have no competing interests.

\section{Authors' contributions}

ACSC and CSP designed the study. CSP and ACSC drafted the manuscript. CSP, HSS, HO, and HC prepared the samples and carried out the ICP-MS analysis. All authors read and approved the final manuscript.

\section{Acknowledgements}

This work was supported by the R\&D Convergence Program of National Research Council of Science \& Technology of Republic of Korea (CAP-15-07-KICT) and Korea Basic Science Institute (C36701). Sanghoon Kwon provided many useful comments and suggestions on the early version of the manuscript.

Received: 29 February 2016 Accepted: 13 May 2016

Published online: 25 June 2016

\section{References}

Borisov OV, Mao X, Russo RE. Effects of crater development on fractionation and signal intensity during laser ablation inductively coupled plasma mass spectrometry. Spectrochim Acta B. 2000;55:1693-704.

Chen Z, Canil D, Longerich HP. Automated in situ trace element analysis of silicate materials by laser ablation-inductively coupled plasma mass spectrometry. Fresenius J Anal Chem. 2000;368:73-8. 
Cotta AJB, Enzweiler J. Classical and new procedures of whole rock dissolution for trace element determination by ICP-MS. Geostand Geoanal Res. 2012;36:27-50.

Eggins SM, Kinsley LPJ, Shelley JM. Deposition and element fractionation processes during atmospheric pressure laser sampling for analysis by ICP-MS. Appl Surf Sci. 1998;127:278-86.

Fan J, Kerrich R. Geochemical characteristics of aluminium depleted and undepleted komatiites and HREE-enriched low-Ti tholeiites, western Abitibi greenstone belt: a heterogeneous mantle plume-convergent margin environment. Geochim Cosmochim Acta. 1997;61:4723-44

Gonzalez J, Mao XL, Roy J, Mao SS, Russo RE. Comparison of 193, 213 and $266 \mathrm{~nm}$ laser ablation ICP-MS. J Anal At Spectrom. 2002;17:1108-13.

Guillong M, Horn I, Gunther D. A comparison of 266 nm, 213 nm and 193 nm produced from a single solid state Nd:YAG laser for laser ablation ICP-MS. J Anal At Spectrom. 2003;18:1224-30.

Hall GEM, Plant JA. Analytical errors in the determination of high field-strength elements and their implications in tectonic interpretation studies. Chem Geol. 1992;95:141-56.

Horn I, Hinton RW, Jackson SE, Longerich HP. Ultra-trace element analysis of NIST SRM 616 and 614 using laser-ablation microprobe-inductively coupled plasma- mass spectrometry (LAM-ICP-MS): a comparison with secondary ion mass spectrometry (SIMS). Geostandards Newsletter J Geostand Geoanal. 1997;21:191-203.

Horn I, Rudnick RL, McDonough WF. Precise elemental and isotope ratio determination by simultaneous solution nebulization and laser ablation-ICP-MS: application to U-Pb geochronology. Chem Geol. 2000;164:281-301.

Hu Z, Gao S, Liu Y, Hu S, Chen H, Yuan H. Signal enhancement in laser ablation ICP-MS by addition of nitrogen in the central channel gas. J Anal At Spectrom. 2008:23:1093-101.

Jackson SE, Longerich HP, Dunning GR, Fryer BJ. The application of laser ablation microprobe-inductively coupled plasma-mass spectrometry (LAM-ICP-MS) to in situ trace element determinations in minerals. Can Mineral. 1992;30:1049-64.

Jochum KP, Stoll B, Herwig K, Willbold M. Validation of LA-ICP-MS trace element analysis of geological glasses using a new solid-state $193 \mathrm{~nm} \mathrm{Nd:YAG} \mathrm{laser}$ and matrix-matched calibration. J Anal At Spectrom. 2007;22:112-21.

Kurosawa M, Shima K, Ishii S, Sasa K. Trace element analysis of fused whole-rock glasses by laser ablation-ICP-MS and PIXE. Geostand Geoanal Res. 2006;30:17-30.

Lahaye Y, Lambert D, Walters S. Ultraviolet laser sampling and high resolution inductively coupled plasma-mass spectrometry of NIST and BCR-2G glass reference materials. Geostandard Newslett. 1997;21:205-14.

Mank ARJ, Mason PRD. A critical assessment of laser ablation ICP-MS as an analytical tool for depth analysis in silica-based glass samples. J Anal At Spectrom. 1999;14:1143-53.

Meisel T, Schoner N, Paliulionyte $V$, Kahr E. Determination of rare earth elements, $\mathrm{Y}, \mathrm{Th}, \mathrm{Zr}, \mathrm{Hf}, \mathrm{Nb}$ and $\mathrm{Ta}$ in geological reference materials G-2, G-3, SCo-1 and WGB-1 by sodium peroxide sintering and inductively coupled plasma-mass spectrometry. Geostandards Newslett. 2002;26:53-61.

Navarro MS, Andrade S, Ulbrich H, Gomes CB, Girardi VAV. The direct determination of rare earth elements in basaltic and related rocks using ICP-MS: testing the efficiency of microwave oven sample decomposition procedures. Geostand Geoanal Res. 2008;32:167-80.

Norman MD, Pearson NJ, Sharma A, Griffin WL. Quantitative analysis of trace elements in geological materials by laser ablation ICPMS: instrumental operating conditions and calibration values of NIST glasses. Geostandard Newslett. 1996;20:247-61

Norman MD, Griffin WL, Pearson NJ, Garcia MO, O'Reilly SY. Quantitative analysis of trace element abundances in glasses and minerals: a comparison of laser ablation inductively coupled plasma-mass spectrometry, solution inductively coupled plasma-mass spectrometry, proton microprobe and electron microprobe data. J Anal At Spectrom. 1998:13:477-82.

Orihashi Y, Hirata T. Rapid quantitative analysis of $Y$ and REE abundances in XRF glass bead for selected GSJ reference rock standards using Nd-YAG 266 nm UV laser ablation ICP-MS. Geochemical J. 2003;37:401-12.

Park CS, Shin HS, Oh H, Moon JH, Cho H, Cheong C. Determination of trace elements in geological reference materials G-3, GSP-2 and SGD-1a by low-dilution glass bead digestion and ICP-MS. Geostand Geoanal Res. 2013;37:361-8.

Rollinson H. Using geochemical data. Singapore: Longman Scientific and Technical; 1993.

Taylor RP, Jackson SE, Webster JL, Longerich HP. In situ trace-element analysis of individual silicate melt inclusions by laser ablation microprobe-inductively coupled plasma-mass spectrometry (LAM-ICP-MS). Geochim Cosmochim Acta. 1997;61:2559-67.
Totland M, Jarvis I, Jarvis KE. An assessment of dissolution techniques for the analysis of geological samples by plasma spectrometry. Chem Geol. 1992;95:35-62.

Totland M, Jarvis I, Jarvis KE. Microwave digestion and alkali fusion procedures for the determination of the platinum-group elements and gold in geological materials by ICP-MS. Chem Geol. 1995;124:21-36.

Wu S, Zhao YH, Feng XB, Wittmeier A. Application of inductively coupled plasmamass spectrometry for total metal determination in silicon-containing solid samples using the microwave-assisted nitric acidhydrogen peroxide-boric acid digestion system. J Anal At Spectrom. 1996;11:287-96.

Yu Z, Robinson P, McGoldrick P. An evaluation of methods for the chemical decomposition of geological materials for trace element determination using ICP-MS. Geostandard Newslett. 2001;25:199-217.

\section{Submit your manuscript to a SpringerOpen ${ }^{\circ}$ journal and benefit from:}

- Convenient online submission

- Rigorous peer review

- Immediate publication on acceptance

- Open access: articles freely available online

- High visibility within the field

- Retaining the copyright to your article

Submit your next manuscript at $>$ springeropen.com 